\title{
Therapeutic Evaluation of the Potential Mechanisms of Anti-Inflammatory Activities of Fagara zanthoxyloides Lam. Leave Extract in Wistar Rats
}

\author{
Emmanuel Sunday Okeke ${ }^{1,2}, 3^{*}$, Osmund Chukwuma Enechi ${ }^{1}$, Nicodemus Emeka Nwankwo ${ }^{1,2}$, Ndidi Ethel \\ Nkwoemeka $^{2}$ \\ ${ }^{1}$ Department of Biochemistry, University of Nigeria, Nsukka, Enugu State Nigeria \\ ${ }^{2}$ Natural Science Unit, School of General Studies, University of Nigeria, Nsukka, Enugu State Nigeria \\ ${ }^{3}$ School of the Environment and Safety Engineering, Jiangsu University, Zhenjiang 212013, PRC \\ *Corresponding author. E mail: emmanuel.okeke@unn.edu.ng \\ Tel: +2348035277554
}

Published: 4 December 2020

\begin{abstract}
Fagara zanthoxyloides is a medicinal plant used in traditional medicine for the treatment of elephantiasis, toothache, sexual impotence, malaria, dysmenorrheal and abdominal pain among rural dwellers. The aim of the present study was to evaluate the in vivo and in vitro anti-inflammatory effect of the methanol extracts of the leaves of Fagara zanthoxyloides to validate its use in folklore medicine. The analysis of the phytochemical content of the leaf extract of Fagara zanthoxliodes revealed the presence of different secondary metabolites (tannins, saponin, terpenoids, steroids, flavonoids, alkaloids, phenols and glycoside) in varying proportions. In the systemic oedema of the rat paw, scalar doses $(50,100$ and $250 \mathrm{mg} / \mathrm{kg} \mathrm{b.w})$ of the extract significantly $(\mathrm{p}<0.05)$ suppressed the development of paw oedema induced by egg albumin at different time intervals $(0.5 \mathrm{hr}-5 \mathrm{hrs})$. This compares well with a standard antiinflammatory drug indomethacin $(10 \mathrm{mg} / \mathrm{kg} \mathrm{b.w})$. Varying doses of the extract $(1.0,1.2,1.4,1.6$ and $1.8 \mathrm{ml})$ significantly $(\mathrm{p}<0.05)$ inhibited phospholipase $\mathrm{A}_{2}$ activity in a concentration-related manner provoking inhibition comparable to that of prednisolone, a standard anti-inflammatory drug. Similarly, the extract significantly $(p<0.05)$ inhibited $\mathrm{CaCl}_{2}$-Induced platelet aggregation in a dose and time dependent manner when compared to the control and the standard drug (indomethacin). The extract also significantly $(\mathrm{p}<0.05)$ inhibited hypotonicity induced membrane stabilization when compared to that control and standard drug (Indomethacin). These results indicate that the extract produced potential anti-inflammatory activity which could be as a result of the rich phytochemical constituents.
\end{abstract}

Keywords: Inflammation, Membrane stabilization, Paw oedema, Phospholipase A2, Platelet aggregation.

\section{Introduction}

Inflammation is a protective mechanism by which the body eliminates stimuli like pathogens, damage cells or irritants thus initiating the body's healing process. ${ }^{1}$ Inflammation has been implicated in several health conditions. The clinical symptoms such as fever, aches and pains associated with several diseases are directly or indirectly due to inflammatory disorders. $^{2}$ Non-steroidal anti-inflammatory agents (NSAIDs) and corticosteroids are the major classes of antiinflammatory agents but their toxic adverse effects such as epigastric distress, peptic ulceration, osteoporosis, and iatrogenic Cushing's syndrome have limited their use., ${ }^{2,3}$ Hence, medicinal plants could provide an excellent fountainhead to develop new anti-inflammatory agents, which could be more efficacious, safer, affordable, and accessible for patients.

Fagara zanthoxyloides Lam. Lam. (family Rutaceae) is a West African tree used in traditional medicine. The rootbark extract is used in treating elephantiasis, toothache, sexual impotence, gonorrhea, malaria, dysmenorrheal and abdominal pain. ${ }^{4}$ In West Africa, the root of Fagara zanthoxyloides Lam. is commonly used indigenously for tooth cleaning as chewing stick and it has been shown that the root extract exhibited a very high antimicrobial activity against oral flora. ${ }^{5}$ The anti-pyretic, analgesic ${ }^{6}$ and anti-inflammatory activities ${ }^{2}$ of the root-bark extract of the plant have been reported. The study evaluated the in vivo and in vitro anti-inflammatory activity of the methanol extract of Fagara zanthoxyloide leaves in Wistar rats.

\section{Materials and Methods}


Plant materials

Fresh leaves of $F$. zanthoxyloides were collected from Opanda-Nimbo in Uzo-uwani Local Government Area of Enugu State, Nigeria in June 2018. The plant was authenticated by Mr. A. O. Ozioko of the International Centre for Ethnomedicine and Drug production (InterCEED), Nsukka Nigeria. Voucher specimen of the plant with No. INTERCEED/059 was deposited at the InterCEED Herbarium. The leaves were identified and authenticated by a taxonomist. The fresh leaves were washed to remove dirt. The leaves were then shade-dried The dried leaves were pulverized into powdered form using a mechanical grinder. The pulverized leaves $(1.5 \mathrm{~kg})$ were macerated in $3.5 \mathrm{~L}$ absolute methanol using a maceration flask. The mixture was left for $72 \mathrm{~h}$ with occasional stirring, after which it was filtered into a flat-bottom flask using a muslin cloth. Further filtration was achieved with Whatman No 1 filter paper so as to remove fine residues. The filtrate was concentrated using a rotary evaporator at $45^{\circ} \mathrm{C}$ to obtain the crude methanol extract. The concentrated extract was stored in a labelled sterile screw-capped bottle in the refrigerator until use for the study.

Chemicals and reagents

Chemicals were all of analytical grade and products of May and Baker England, British Drug House (BDH) England, Fluka Germany, Burgoyne, India, Harkin and Williams, England and Sigma Aldrich.

\section{Animals}

Adult male Wistar rats (120 -130 g) were purchased from the animal house of the Department of Zoology and Environmental Biology, University of Nigeria, Nsukka. The animals were grouped into five groups, each containing five rats. The animals were acclimatized for one week prior to the commencement of experiment with a $12 \mathrm{~h}$ light and dark cycle and maintained on a regular feed (commercial chicken grower's mash) and water ad labium at the department animal house. The experimental protocols were in accordance with the ethical rules and recommendations of the University of Nigeria committee on the care and use of laboratory animals and the revised National Institute of Health Guide for Care and Use of Laboratory Animal (Pub No.85-23, revised 1985).

\section{Ethical clearance}

Clearance and approval (with approval number UN/ZEB/2125) for conducive experimental conditions and humane use and handling of laboratory animals were given by the ethical committee of the Department of Zoology and Environmental Biology, University of Nigeria Nsukka.

\section{Quantitative phytochemical screening}

The preliminary phytochemical screening of the methanol leaves extract of $F$. zanthoxyloides was carried out to ascertain the presence of some plant secondary metabolites and thus those detected were further quantified. Both determinations were done by utilizing standard conventional protocols. ${ }^{7}$

Effect of methanol extract of Fagara zanthoxyloides Lam. leaves on egg-albumin induced paw oedema This was done according to the method of Winter et al. ${ }^{8}$ The increase in the right hind paw size of the rats induced by the sub-plantar injection of freshly prepared egg albumin was used as a measure of acute inflammation. The animals were fasted for $18 \mathrm{~h}$ to prior the experiment. The animals received normal saline, Indomethacin $(10 \mathrm{mg} / \mathrm{kg}$, orally), or extract $(50,100$ and $250 \mathrm{mg} / \mathrm{kg}$ i.p) respectively which are within the lethal dose. Inflammation was induced by subplantar injection of the right hind paw of the animals. The right hind paw size of the rats at time zero (before the induction of oedema) were measured using a vernier calliper. One hour after administration of the test substances, acute inflammation was induced by injecting $0.1 \mathrm{~mL}$ of freshly prepared egg albumin into the subplantar area of the right hind paw of the rats. The increase in the right hind paw size of rats was subsequently measured at $0.5,1,2,3,4$ and $5 \mathrm{~h}$ after egg albumin injection. The difference between the paw size of the injected paws at time zero and at different times after egg albumin injection was used to assess the formation of oedema. These values were used in the calculation of the percentage inhibition of oedema for each dose of the extract and for indomethacin at the different time intervals using the relation:

$\%$ Inhibition of oedema $=100 \mathrm{X}(\mathrm{Vc}-\mathrm{Vt} / \mathrm{Vc})$

Where; $\mathrm{V}_{\mathrm{c}}=$ Mean paw oedema volume of control group

$\mathrm{V}_{\mathrm{t}}=$ Paw oedema at time $\mathrm{t}(0.5,1,2,3,4,5 \mathrm{~h})$ 


\section{sciforum}

Effect of methanol extract of Fagara zanthoxyloides Lam. leaves on Phospholipase $A_{2}$ activity

The effect of the extract on phospholipase $A_{2}$ activity was determined using modifications of the methods of Vane. ${ }^{9}$ Phospholipase $\mathrm{A}_{2}$ activity was assayed using its action on erythrocyte membrane. It releases free fatty acids from the membrane phospholipids thereby causing leakage, allowing haemoglobin to flow into the medium in the process. The enzyme activity is thus directly related to the amount of haemoglobin in the medium.

\section{Enzyme preparation}

Fungal enzyme preparation was obtained from Aspergillus niger strain culture. The nutrient broth was prepared by dissolving $15 \mathrm{~g}$ of Sabouraud dextrose agar in $1000 \mathrm{~mL}$ of distilled water, homogenized in a water bath for $10 \mathrm{~min}$ and dispensed into $250 \mathrm{~mL}$ conical flasks. The conical flasks were sealed with cotton wool and foil paper. The broth was then autoclaved at $121^{\circ} \mathrm{C}$ for 15 minutes. The broth was allowed to cool to room temperature and then the organisms in the Petri dishes were aseptically inoculated into the broth and incubated for $72 \mathrm{~h}$ at room temperature. The culture was transferred into test tubes containing $3 \mathrm{~mL}$ phosphate buffered saline and centrifuged at $3000 \mathrm{rpm}$ for $10 \mathrm{~min}$. The fungal cells settled at the bottom of the test tube while the supernatant was used as the crude enzyme preparation.

\section{Substrate preparation}

Fresh human blood samples (healthy volunteer who has not taken any form of NSAID for at least two weeks- from whom informed consent was obtained) were centrifuged at 3,000 rpm for $10 \mathrm{~min}$ and the supernatant (plasma) discarded. The red cells were washed three times with equal volume of normal saline, measured and reconstituted as a $40 \%(\mathrm{v} / \mathrm{v})$ suspension with phosphate buffered saline. This served as the substrate for phospholipase $\mathrm{A}_{2}$.

\section{Assay procedure}

$\mathrm{CaCl}_{2}(2 \mathrm{mM})(0.2 \mathrm{~mL})$, human red blood cell (HRBC) $(0.2 \mathrm{~mL}), 0.2 \mathrm{~mL}$ of the crude enzyme preparation and varying concentrations of normal saline, the extract and the reference drug (prednisolone) were incubated in test-tubes for 1 h. The control contained the human red blood cell suspension, $\mathrm{CaCl}_{2}$ and free enzyme. The blanks were treated with $0.2 \mathrm{~mL}$ of boiled enzyme separately. The incubation reaction mixtures were centrifuged at $3000 \mathrm{x} g$ for $10 \mathrm{~min}$. Samples of the supernatant $(1.5 \mathrm{~mL})$ were diluted with $10 \mathrm{~mL}$ of normal saline and the absorbance of the solutions was read at $418 \mathrm{~nm}$. Prednisolone, a known inhibitor of phospholipase $\mathrm{A}_{2}$, was used as the reference drug. The percentage maximum enzyme activity and percentage inhibition were calculated using the following relationship:

\footnotetext{
$\%$ Maximun enzyme activity $=\mathrm{OD}_{\text {Test }} / \mathrm{OD}_{\text {Control }}$ X 100

$\%$ Inhibition $=100-\%$ maximum enzyme activity
}

Effect of methanol extract of Fagara zanthoxyloides Lam. leaves on Platelet aggregation

The modified method of Born and Cross ${ }^{10}$ was used to determine the anti-platelet activity. Fresh blood samples (5 $\mathrm{mL}$ ) from healthy volunteer (from whom informed consent was obtained) who has not taken any form of NSAID for at least two weeks were drawn intravenously using $5 \mathrm{~mL}$ plastic syringe into plastic tubes containing $1 \%$ EDTA as an anticoagulant. The tubes were centrifuged at $3000 \mathrm{rpm}$ for $10 \mathrm{~min}$ and the supernatant was collected, diluted twice with normal saline and used as the platelet rich plasma (PRP). Changes in absorption of the platelet rich plasma (PRP) were determined. PRP $(0.2 \mathrm{~mL}), 0.4 \mathrm{~mL}$ of $2 \mathrm{M} \mathrm{CaCl}_{2}$, varying concentrations of normal saline $(1.5,1.4,1.2,1.0 \mathrm{~mL})$ and extract $(0.1,0.2,0.4,0.6 \mathrm{mg} / \mathrm{mL})$ were incubated at room temperature for $2 \mathrm{~min}$. The absorbances of the solutions were measured at $520 \mathrm{~nm}$. Changes in absorption at $520 \mathrm{~nm}$ were taken at intervals of 2 min for $8 \mathrm{~min}$. Indomethacin was used as the reference drug.

$\%$ Inhibition $=\mathrm{OD}_{\text {Test }} / \mathrm{OD}_{\text {Control }} \mathrm{X} 100$

Effect of methanol extract of Fagara zanthoxyloides Lam. leaves on membrane stabilization (Hypotonicity-induced Haemolysis of Red Blood Cells)

The effect of extract on hypotonicity was investigated using the method of Shinde et al. ${ }^{11}$ Fresh blood sample $(5 \mathrm{~mL})$ was collected from healthy volunteers into plastic tubes containing $0.01 \mathrm{~mL}$ of $1 \%$ EDTA to prevent coagulation. These tubes were centrifuged at $3000 \mathrm{rpm}$ for $15 \mathrm{~min}$. The supernatant was collected and discarded. Twice the volume of normal saline equivalent to the volume of the supernatant was used to redissolve the red blood cell pellet for use, sixteen test tubes were used. Eight for the main test and the other eight as the blanks for each test tube. The test tube 
1 contained $0.1 \mathrm{~mL}$ of blood and $2.4 \mathrm{~mL}$ of normal saline. Test tube 2 contained $0.1 \mathrm{~mL}$ of blood, $1.9 \mathrm{~mL}$ of normal saline and $0.5 \mathrm{~mL}$ of distilled water. Test tube 3-6 contained the same volume of blood and distilled water but varying volumes of extract and normal saline. Test tubes 7 and 8 contained the same volume of blood and distilled water but varying volumes of indomethacin and normal saline. The volume of each test tube was $2.5 \mathrm{~mL}$. Subsequently, the test tubes were incubated for $1 \mathrm{~h}$ at $37^{\circ} \mathrm{C}$ in a water bath. After the incubation, the test tubes were centrifuged at $3000 \mathrm{rpm}$ for $20 \mathrm{~min}$ to terminate the reaction. The absorbance of the supernatants collected was read at $540 \mathrm{~nm}$. These experiments were done in triplicates and mean absorbance value taken. The percentage inhibition of haemolysis was evaluated using the following relation:

$$
\% \text { inhibiton of haemolysis }=100\left(1-\frac{\mathrm{OD} 2-\mathrm{OD} 1}{\mathrm{OD} 3-\mathrm{OD} 1}\right)
$$

Where; OD1 = Absorbance of control I (isotonic solution)

OD2 = Absorbance of test sample

OD3 $=$ Absorbance of control II (hypotonic solution)

\section{Statistical analysis}

The data obtained were analyzed using both one and two-way analysis of variance (ANOVA) in Statistical product and Service Solution (SPSS) version 22.0 and presented as Mean \pm SD. Mean values with $p<0.05$ of the result was accepted significant.

\section{Results and Discussion}

Quantitative phytochemical evaluation of crude extract of Fagara zanthoxyloides

Table 1 shows the results of the quantitative phytochemical constituents of the methanol extract of Fagara zanthoxyloides. The results revealed the presence of tannins, saponins, terpenoids, steroids, flavonoids, alkaloids, phenols and glycosides in different proportions. The phytochemical constituents in the methanol extract of $F$. zanthoxyloides leaves could be responsible for its anti-inflammatory properties.

\section{Effect of methanol extract of Fagara zanthoxyloides Lam. leaves on egg-albumin induced paw oedema}

The result of the effect of methanol extract of F.zanthoxyloides leaves on egg-albumin induced paw oedema showed a decrease in the mean sizes of the paw across the different time intervals for all groups (Table 2). At the time intervals, $0.5-5 \mathrm{~h}$, there were significant $(\mathrm{p}<0.05)$ differences between the mean sizes of the paw for the different concentrations of the extracts $(50,100,250 \mathrm{mg} / \mathrm{kg})$ when compared to the control. Also, there was an increase in the percentage inhibition across the time interval for the treated groups. The egg-albumin-induced paw oedema model was used to screen the in vivo anti-inflammatory activity of this plant. The resultant swelling of the paw after the administration of the egg-albumin is due to oedema formation. The formation of oedema arises from the action of inflammatory mediators such as histamine, serotonin and bradykinin which work in synergy at the site of a local inflammatory insult ${ }^{12}$ leading to increased permeability of vessels and blood flow. The early phase of oedema which starts immediately after the administration of the irritant and lasting up to $2 \mathrm{~h}$ is probably due to the release of histamine, 5-hydroxyltryptamine, kinins and serotonin, while the later phase which is from $3 \mathrm{~h}$ to $5 \mathrm{~h}$ after administration of the irritant is induced by bradykinin, protease, prostaglandins and lysosome. ${ }^{12,13}$ Sub-plantar injection of egg-albumin into the paw produces oedema resulting from extravasation, increased tissue water and plasma protein exudation along with neutrophil extravasation. ${ }^{14}$ The extract reduced the mean sizes of the egg-albumin induced paw oedema for all groups at the different time intervals and the percentage inhibition of the different treatment groups increased with increasing time intervals. The reduction of the oedema in the first phase by the extracts at high dose, suggests that it contains active constituents which inhibit the release or action of the early phase mediators, thereby reducing vascular permeability, fluid exudation and thus, suppressing oedema. Suppression of oedema in the second phase of inflammation suggests that the anti-inflammatory activity of the leaf extracts may also be due to the inhibition of phlogistic mediators such as prostaglandins, antagonizing their interaction with their respective receptors or it may be due to general mechanism like increasing the membrane stability of the cell or suppression of kinin formation induced by the egg-albumin within this period. 
Table 3 shows the effect of methanol extract of Fagara zanthoxyloides Lam. leaves on phospholipase $\mathrm{A}_{2}$ activity. There was a significant decrease $(\mathrm{p}<0.05)$ in the absorbance of the sample with increasing concentration of the extract hence a decrease in enzyme activity when compared to the control. Prednisolone followed a similar trend (with the extract) of enzyme activity decreasing with increasing concentration of prednisolone. The absorbances of varying concentrations of the extracts $(1.0,1.2,1.4,1.6,1.8 \mathrm{mg} / \mathrm{ml})$ were significantly $(\mathrm{p}<0.05)$ lower when compared to the control, similar effects were observed with increasing concentrations of prednisolone when compared to the control. The methanol leaf extract of $F$. zanthoxyloides was highly effective in inhibiting phospholipase $\mathrm{A}_{2}$ activity. Enzyme inhibitory activity may be due to interference with calcium utilization. Calcium ion is bound to the catalytic site of the enzyme and directs coordination of substrate carbonyl oxygen atom. ${ }^{15}$ Phospholipase $\mathrm{A}_{2}$ cleaves free fatty acid from erythrocyte phospholipids. The enzyme activity assayed using its action on erythrocyte membrane, creates leakage thus causing haemoglobin to flow out into the medium. Inhibition of phospholipase $A_{2}$ implies that the methanol extract of F. zanthoxyloides leaves may suppress the mobilisation of free fatty acids from membrane phospholipids. It has been reported that anti-inflammatory and immunosuppressive steroids inhibit arachidonic acid and its metabolites. ${ }^{16}$ The results were similar to the findings reported by Okeke et al on the root-bark extract of the plant.

\section{Effect of methanol extract of Fagara zanthoxyloides Lam. leaves on Platelet aggregation}

The result of the effect of methanol extract of Fagara zanthoxyloides Lam. leaves on platelet aggregation (Table 4) showed an increase in the absorbance values of the different concentrations of the extracts compared to the standard control across the different time intervals. The extract at $0.1 \mathrm{mg} / \mathrm{mL}$ gave a percentage inhibition of $75 \%$ at the $8^{\text {th }}$ minute when compared with the standard controls $(0.4,0.6 \mathrm{mg} / \mathrm{mL})$ which gave $61 \%$ and $57 \%$ at the $8^{\text {th }}$ minutes, respectively. The role of platelets in the inflammatory processes is being increasingly recognized, in addition to their function in haemostasis and thrombosis. ${ }^{17}$

Platelets accumulate in inflammatory sites concomitantly with leukocytes ${ }^{18}$ and regulate a variety of inflammatory response by secreting or activating adhesion proteins, growth factors, chemokines, cytokine-like factors and coagulation factors. These proteins induce widely differing biological activities, including cell adhesion chemotaxis, cell survival, and proliferation, all of which accelerate inflammatory process. ${ }^{19}$ Maximum platelet aggregation was attained at the $6^{\text {th }}$ minute. The percentage inhibition of platelet aggregation increases with increase in time. This shows that the inhibition of platelet aggregation by the extract is concentration-dependent and is consistent with the findings of Okeke et al. ${ }^{2}$ on the root-bark extract of the plant.

\section{Effect of methanol extract of Fagara zanthoxyloides Lam. leaves on hypotonicity-induced haemolysis of red blood} Cells

The extract at different concentrations protected significantly $(\mathrm{P}<0.05)$ the erythrocyte membrane against lysis induced by hypotonic solution when compared to the control (Table 5). As the concentration of extract increased the percentage inhibition increased simultaneously. Reduction in the absorbance reading of the different concentrations of the extracts was indicative of the effect of the membrane stabilizing properties of the extracts. The methanol extract of $F$. zanthoxyloides leaves were found to exhibit high membrane stabilization effect against hypotonicity-induced haemolysis of the red cells as is shown by the level of inhibition of haemolysis. Protection against hypotonicityinduced haemolysis is related to membrane stabilization which is an anti-inflammatory index. ${ }^{20}$ The inhibition of haemolysis was found to be dose-dependent and was comparable to that of indomethacin. Hypotonicity-induced haemolysis of human red blood cells (HRBC) occurs due to water uptake by the cells and leads to the release of haemoglobin which absorbs maximally at $540 \mathrm{~nm}$. Hence, the reduced optical density at $540 \mathrm{~nm}$ obtained for the various $F$. zanthoxyloides test samples was a reflection of the stabilization of the red cell membrane caused by the extract.

\section{Conclusion}

It can be concluded that the methanol extract of the leaves of $F$. zanthoxyloides possess anti-inflammatory activity thus validating the ethnopharmacological claims. This anti-inflammatory activity could be due to the inhibition of histamine, serotonin and bradykinin, phlogistic mediators such as prostaglandins, inhibition of phospholipase $\mathrm{A}_{2}$ activity, the extract's ability to inhibit platelet aggregation and protection against hypotonicity-induced haemolysis which is an anti-inflammatory index. This knowledge could hence be tapped to formulate new agents that will be easily affordable with reduced side effects for the treatment of inflammatory ailments as against chemically synthetic drugs used as anti-inflammatory agents with side effects. 


\section{sciforum}

\section{Conflict of Interest}

The authors declare no conflict of interest.

\section{Authors' Declaration}

The authors hereby declare that the work presented in this article are original and that any liability for claims relating to the content of this article will be borne by them.

\section{Acknowledgements}

The authors wish to thank the technical staff of the Natural Science Unit, School of General Studies, University of Nigeria, Nsukka for their technical assistance during the study.

Table 1: Quantitative Phytochemical Constituent of Fagara zanthoxyloides Lam. Extract

\begin{tabular}{ll}
\hline Phytochemical constituent (\%) & Amount \\
\hline Tannins & $13.510 \pm 1.085$ \\
Saponin & $0.653 \pm 0.110$ \\
Terpenoid & $905.298 \pm 10.144$ \\
Steroids & $0.713 \pm 0.153$ \\
Flavonoids & $1592.593 \pm 8.900$ \\
Alkaloids & $156.097 \pm 4.531$ \\
Phenols & $699.140 \pm 2.612$ \\
Glycosides & $128.223 \pm 0.936$ \\
\hline
\end{tabular}

Table 2: Effect of methanol extract of Fagara zanthoxyloides Lam. leaves on egg-albumin induced paw oedema

\begin{tabular}{|c|c|c|c|c|c|c|}
\hline \multicolumn{3}{|l|}{ Treatment Group } & Mean Paw Size & \multirow{2}{*}{$\begin{array}{l}\text { (cm) and } \\
3 \mathrm{~h}\end{array}$} & \multicolumn{2}{|l|}{ Duration } \\
\hline & $0.5 \mathrm{~h}$ & $1 \mathrm{~h}$ & $2 \mathrm{~h}$ & & $4 \mathrm{~h}$ & $5 \mathrm{~h}$ \\
\hline Control (normal saline) & $3.308 \pm 0.556^{\mathrm{aA}}$ & $3.713 \pm 0.707^{\mathrm{aB}}$ & $4.355 \pm 1.021^{\mathrm{abB}}$ & $5.055 \pm 0.526^{\mathrm{bB}}$ & $5.450 \pm 0.933^{\mathrm{bB}}$ & $5.580 \pm 0.828^{\mathrm{bB}}$ \\
\hline Indomethacin & $3.083 \pm 0.611^{\mathrm{dA}}$ & $2.550 \pm 0.274^{\mathrm{cdA}}$ & $2.393 \pm 0.313^{\mathrm{bcA}}$ & $2.113 \pm 0.332^{\mathrm{abcA}}$ & $1.845 \pm 0.337^{\mathrm{abA}}$ & $1.753 \pm 0.331^{\mathrm{aA}}$ \\
\hline$(10 \mathrm{mg} / \mathrm{kg} \mathrm{b} . \mathrm{w})$ & $\diamond 6.80$ & $\diamond 31.32$ & $\diamond 45.05$ & $\diamond 58.29$ & $\diamond 66.15$ & $\diamond 68.58$ \\
\hline Extract & $2.573 \pm 0.228^{\mathrm{bA}}$ & $2.328 \pm 0.517^{\mathrm{abA}}$ & $2.270 \pm 0.469^{\mathrm{abA}}$ & $1.975 \pm 0.512^{\mathrm{abA}}$ & $1.890 \pm 0.464^{\mathrm{abA}}$ & $1.798 \pm 0.480^{\mathrm{aA}}$ \\
\hline$(50 \mathrm{mg} / \mathrm{kg} \mathrm{b} . \mathrm{w})$ & $\diamond 22.22$ & $\diamond 37.30$ & $\diamond 47.88$ & $\diamond 60.93$ & $\diamond 65.32$ & $\diamond 67.78$ \\
\hline Extract & $3.105 \pm 0.236^{\mathrm{cA}}$ & $2.428 \pm 0.706^{\mathrm{bA}}$ & $1.880 \pm 0.545^{\mathrm{abA}}$ & $1.568 \pm 0.443^{\mathrm{aA}}$ & $1.398 \pm 0.289^{\mathrm{aA}}$ & $1.290 \pm 0.327^{\mathrm{aA}}$ \\
\hline (100 mg/kg b. w) & $\diamond 6.14$ & $\diamond 34.61$ & $\diamond 56.83$ & $\diamond 68.98$ & $\diamond 74.35$ & $\diamond 76.88$ \\
\hline Extract & $2.903 \pm 0.651^{\mathrm{bA}}$ & $2.390 \pm 0.962^{\mathrm{abA}}$ & $1.983 \pm 0.703^{\mathrm{abA}}$ & $1.713 \pm 0.608^{\mathrm{aA}}$ & $1.523 \pm 0.677^{\mathrm{aA}}$ & $1.345 \pm 0.671^{\mathrm{aA}}$ \\
\hline$(250 \mathrm{mg} / \mathrm{kg} \mathrm{b} . \mathrm{w})$ & $\diamond 12.24$ & $\diamond 35.63$ & $\diamond 54.46$ & $\diamond 66.11$ & $\Delta 72.06$ & 075.89 \\
\hline
\end{tabular}

Values are expressed as Mean $\pm \mathrm{SD}, \mathrm{n}=5$. $\diamond$ Represents percentage inhibition of paw oedema calculated relative to control.

Mean values having different lowercase letters as superscripts are considered significant $(p<0.05)$ down the column.

Mean values having different uppercase letters as superscripts are considered significant $(p<0.05)$ across the row.

Table 3: Effect of Methanol Extract of Fagara zanthoxyloides Lam. Leaf on Phospholipase $\mathrm{A}_{2}$ Activity

\begin{tabular}{lllllllll}
\hline Treatment & $\begin{array}{l}\text { Extract/Drug } \\
(\mathrm{mg} / \mathrm{mL})\end{array}$ & $\begin{array}{l}\text { Normal } \\
\text { saline } \\
(\mathbf{m L})\end{array}$ & $\begin{array}{l}\mathbf{H R B C} \\
(\mathbf{m L})\end{array}$ & $\begin{array}{l}\mathbf{C E} \\
(\mathbf{m L})\end{array}$ & $\begin{array}{l}\mathbf{C a C l}_{\mathbf{2}} \\
(\mathbf{m L})\end{array}$ & $\begin{array}{l}\text { Absorbance } \\
\mathbf{4 1 8} \mathbf{n m})\end{array}$ & $\begin{array}{l}\text { \% Maximum } \\
\text { Enzyme } \\
\text { Activity }\end{array}$ & $\begin{array}{l}\text { \% } \\
\text { Inhibition }\end{array}$ \\
\hline Control & -- & 2.0 & 0.2 & 0.2 & 0.2 & $1.788 \pm 0.002^{\mathrm{i}}$ & \\
\hline
\end{tabular}




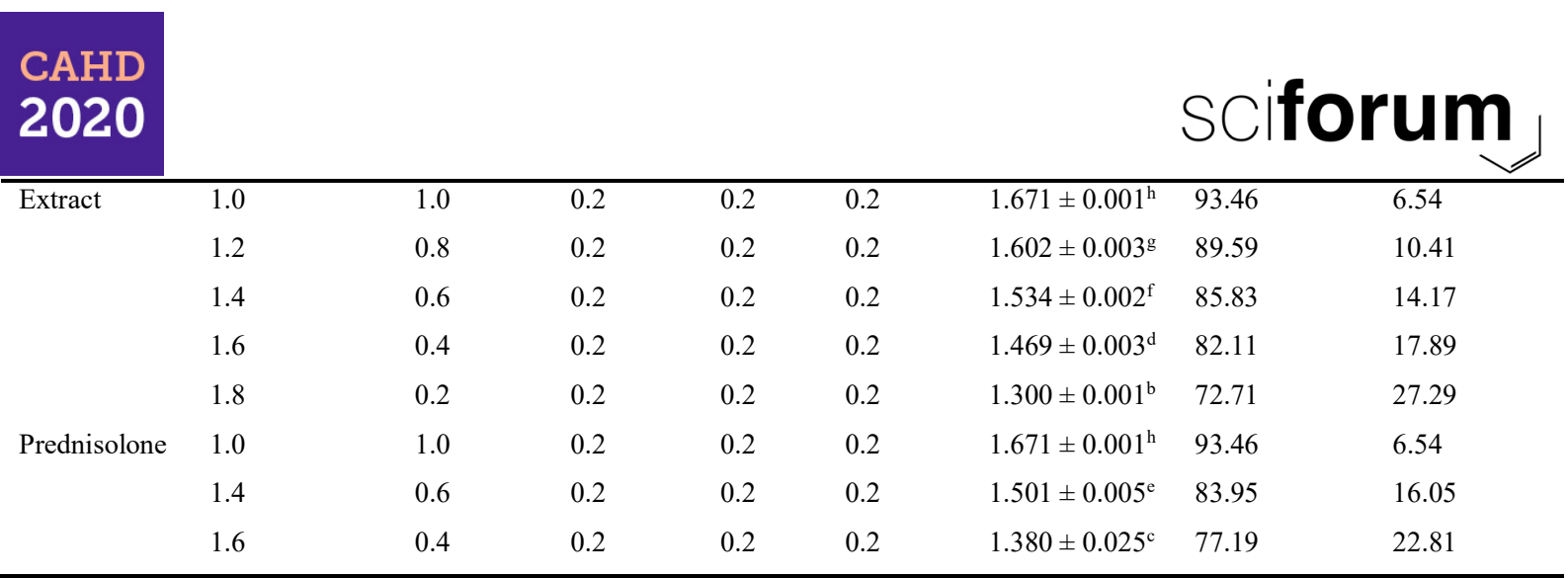

Values are expressed as Mean $\pm \mathrm{SD}, \mathrm{n}=3$.

Mean values having different lowercase letters as superscripts are considered significant $(p<0.05)$ down the column CE: Crude enzyme, HRBC: Human red blood cells

Table 4: Effect of Extract of Fagara Zanthoxyloide on Platelet Aggregation

\begin{tabular}{|c|c|c|c|c|c|c|c|c|c|}
\hline \multirow[t]{2}{*}{ Group } & \multirow[t]{2}{*}{$\begin{array}{l}\text { Extract } \\
(\mathrm{mg} / \mathrm{mL})\end{array}$} & \multirow[t]{2}{*}{$\begin{array}{l}\text { Drug } \\
(\mathrm{mg} / \mathrm{mL})\end{array}$} & \multirow{2}{*}{$\begin{array}{l}\text { N.S } \\
\text { (mL } \\
\text { ) }\end{array}$} & \multirow[t]{2}{*}{$\begin{array}{l}\text { PRP } \\
(\mathrm{mL})\end{array}$} & \multirow[t]{2}{*}{$\mathrm{CaCl}_{2}$} & \multicolumn{3}{|c|}{$\begin{array}{c}\text { Absorbance } \\
(520 \mathrm{~nm})\end{array}$} & \multirow[b]{2}{*}{$8 \mathrm{~min}$} \\
\hline & & & & & & $2 \mathrm{~min}$ & $4 \mathrm{~min}$ & $6 \mathrm{~min}$ & \\
\hline Control & - & - & 1.6 & 0.2 & 0.2 & $0.552 \pm 0.001^{\mathrm{Af}}$ & $0.555 \pm 0.001^{\mathrm{Bf}}$ & $0.557 \pm 0.001^{\mathrm{Cg}}$ & $0.559 \pm 0.001^{\mathrm{Cg}}$ \\
\hline \multirow[t]{8}{*}{ Extract } & 0.1 & - & 1.5 & 0.2 & 0.2 & $0.372 \pm 0.003^{\mathrm{Ae}}$ & $0.377 \pm 0.001^{\mathrm{Be}}$ & $0.399 \pm 0.001^{\mathrm{Cf}}$ & $0.421 \pm 0.002^{\mathrm{Df}}$ \\
\hline & & & & & & $(67 \%)$ & $(68 \%)$ & $(72 \%)$ & $(75 \%)$ \\
\hline & 0.2 & - & 1.4 & 0.2 & 0.2 & $0.360 \pm 0.001^{\mathrm{Ad}}$ & $0.372 \pm 0.003^{\mathrm{Bd}}$ & $0.393 \pm 0.001^{\mathrm{Ce}}$ & $0.400 \pm 0.001^{\mathrm{De}}$ \\
\hline & & & & & & $(65 \%)$ & $(67 \%)$ & $(71 \%)$ & $(72 \%)$ \\
\hline & 0.4 & - & 1.2 & 0.2 & 0.2 & $0.340 \pm 0.000^{\mathrm{Ac}}$ & $0.357 \pm 0.003^{\mathrm{Bc}}$ & $0.359 \pm 0.003^{\mathrm{Bd}}$ & $0.367 \pm 0.002^{\mathrm{Cd}}$ \\
\hline & & & & & & $(62 \%)$ & $(64 \%)$ & $(64 \%)$ & $(67 \%)$ \\
\hline & 0.6 & - & 1.0 & 0.2 & 0.2 & $0.321 \pm 0.004^{\mathrm{Ab}}$ & $0.332 \pm 0.001^{\mathrm{Bb}}$ & $0.343 \pm 0.003^{\mathrm{Cc}}$ & $0.355 \pm 0.003^{\mathrm{Dc}}$ \\
\hline & & & & & & $(58 \%)$ & $(60 \%)$ & $(62 \%)$ & $(64 \%)$ \\
\hline \multirow[t]{3}{*}{ Indomethacin } & - & 0.4 & 1.4 & 0.2 & 0.2 & $0.327 \pm 0.001^{\mathrm{Ab}}$ & $0.330 \pm 0.000^{\mathrm{Bb}}$ & $0.337 \pm 0.002^{\mathrm{Cb}}$ & $0.341 \pm 0.001^{\mathrm{Db}}$ \\
\hline & & & & & & $(59 \%)$ & $(60 \%)$ & $(61 \%)$ & $(61 \%)$ \\
\hline & - & 0.6 & 1.6 & 0.2 & 0.2 & $0.296 \pm 0.008^{\mathrm{Aa}}$ & $0.307 \pm 0.002^{\mathrm{Ba}}$ & $0.316 \pm 0.001^{\mathrm{Ca}}$ & $0.319 \pm 0.002^{\mathrm{Ca}}$ \\
\hline
\end{tabular}

Values are expressed as Mean \pm S.D, $n=3$. ( ) $=\%$ Inhibition.

Mean values having different lowercase letters as superscripts are considered significant $(p<0.05)$ down the column

Mean values having different lowercase letters as superscripts are considered significant $(p<0.05)$ down the row

PRP $=$ Platelet-Rich Plasma, N.S = Normal Saline

Table 5: Effect of the extract of Fagara zanthoxyloide on hypotonicity-induced haemolysis in RBC

\begin{tabular}{|c|c|c|c|c|c|c|c|}
\hline Test tube & HRBC (ml) & $\begin{array}{l}\text { Normal } \\
\text { Saline (mL) }\end{array}$ & $\begin{array}{l}\text { Distilled water } \\
\text { (mL) }\end{array}$ & $\begin{array}{l}\text { Extract } \\
(\mathrm{mg} / \mathrm{mL})\end{array}$ & $\begin{array}{l}\text { Indomethacin } \\
(\mathrm{mg} / \mathrm{mL})\end{array}$ & OD at $540 \mathrm{~nm}$ & $\begin{array}{l}\text { Inhibition } \\
(\%)\end{array}$ \\
\hline 1 & 0.1 & 2.4 & - & - & - & $0.261 \pm 0.009^{d}$ & - \\
\hline 2 & 0.1 & 1.9 & 0.5 & - & - & $0.460 \pm 0.001^{\mathrm{g}}$ & - \\
\hline 3 & 0.1 & 1.8 & 0.5 & 0.1 & - & $0.385 \pm 0.002^{\mathrm{f}}$ & 16 \\
\hline 4 & 0.1 & 1.7 & 0.5 & 0.2 & - & $0.333 \pm 0.003^{\mathrm{e}}$ & 28 \\
\hline 5 & 0.1 & 1.5 & 0.5 & 0.4 & - & $0.225 \pm 0.005^{\mathrm{b}}$ & 51 \\
\hline 6 & 0.1 & 1.3 & 0.5 & 0.6 & - & $0.206 \pm 0.006^{\mathrm{c}}$ & 55 \\
\hline 7 & 0.1 & 1.3 & 0.5 & - & 0.4 & $0.219 \pm 0.002^{\mathrm{b}}$ & 52 \\
\hline 8 & 0.1 & 1.3 & 0.5 & - & 0.6 & $0.200 \pm 0.001^{\mathrm{a}}$ & 57 \\
\hline
\end{tabular}


Values are expressed as Mean \pm S.D. Mean, $\mathrm{n}=3$. Values having different lowercase letters as superscripts are considered significant ( $\mathrm{p}$ $<0.05)$ down.

\section{References}

1. Paliwal SK, Sati B, Faujdar S, Sharma S. Studies on analgesic, anti-inflammatory activities of stem and roots of Inula cuspidata C.B Clarke. J Trad Compl Med. 2017; 7:532-537.

2. Okeke ES, Enechi OC, Nwankwo NE, Nwodo OFC. Evaluation of the Phytochemical Constituents and Anti-Inflammatory Potential of Fagara zanthoxyloides Lam. Root-Bark using in Vivo and In Vitro Models. Pharmacol Online 2019; 2:212-224.

3. Chrousos GP. Basic and clinical pharmacology. In: Katzung BG, Masters SB, Trevor AJ, eds. Adrenocorticosteroids and Adrenocortical Antagonists. 12th ed. New York, NY: McGraw-Hill; 2012. 697-711 p.

4. Grosser T, Smyth E, Fitzgerald GA. Goodman and Gilman's the pharmacological basis of therapeutics. In: Brunton L, ed. Antiinflammatory, Antipyretic and Analgesic Agents: Pharmacotherapy of Gout. 12th ed. New York, NY: McGraw-Hill, 2011. 959$1000 \mathrm{p}$.

5. Olakunle OK, Mark L, Biaffra E, Andrew G, Henrietta A, Victor RG. Effects of root extracts of Fagara zanthoxyloides Lam. on the in vitro growth and stage distribution of Plasmodium falciparum, Antimicrob Agents Chemother. 2005; 49(1):246-268.

6. Okeke ES, Enechi OC, Nwodo OFC. Evaluation of the Phytochemical Screening, Anti-Pyretic and Analgesic Activities of Extract of Fagara Zanthoxyloies Root-Bark, PharmacologyOnline. 2019; 2:152-160.

7. Trease GE, Evans WC (1989) Trease and Evans pharmacognosy. W. B. Saunders, New York. p 585.

8. Winter CA, Risley EA, Nuss GL. Carrageenan-induced oedema in hind limb paw of the rats as an assay for anti-inflammatory drugs, Proc Soc Exp Bio and Med. 1962; 111: 544-557.

9. Vane JR, Inhibition of prostaglandin synthesis as a mechanism of action for aspirin like drugs, Nat New Biol. 1971; 231: 232235

10. Born GVR, Cross MJ. The aggregation of blood platelets, J Physiol. 1963; 168: 178-195.

11. Shinde UA, Phadke AS, Nair AM, Mugantiwar AA, Dikshit VJ, Saraf VO. Membrane stabilizing activity -a possible mechanism of action for the anti-inflammatory activity of Cedrus deodara wood oil. Fitoterapia. 1999; 70 (3): 251-257.

12. Harriot M, Marion E, Martha A, Wellford S, William A. Inflammation induced by histamine, serotonine, bradykinin and compound 48/480 in the rat: Antagonists and mechanisms of action, J Pharmacol Exp Ther. 2004; 191: 300-305.

13. Wallace JM. Nutritional and botanical modulation of the inflammatory cascade: Eicosanoids, cyclooxygenase and lipoxygenaseas an adjunct in cancer therapy, Integr Cancer Therapy. 2002; 1: 7-37.

14. Chatpaliwar VA, Johrapurkar AA, Wanjari MM, Chakraborty RR, Kharkar VT. Anti-inflammatory activity of Martyniadiandraglox, Indiana Drug. 2002; 39: 543-545.

15. Robert SR, Michael HG. Secretory phospholipase A2: A multifaceted family of proatherogenic enzymes. Current Cardio Reps. 2009; 11: 445-451.

16. Schimmer BP, Parker KL. Adrenocorticotropic hormone; adrenocortical steroids and their synthetic analogs; inhibitors of the synthesis and actions of adrenocortical hormones. In: Gilman A G, Hardman J G and Limbird L E, Eds. The Pharmacological Basis of Therapeutics, 10th Edition, The McGraw-Hill Companies, New York,2001. pp.1635-1648.

17. Tamagawa-Mineoka R, Katoh N, Ueda E, Takenaka H, Kita M, Kishimoto S. The role of platelets in leukocyte recruitment in chronic contact hypersensitivity induced by repeated elicitation. Am J Pathol. 2007; 170(6): 2019-2029.

18. Schmitt-Sody M, Klose A, Gottschalk O, Metz P, Gebhard H, Zysk S, Eichhorn ME, Hernandez-Richter TM, Veihelmann, A. Platelet-endothelial cell interactions in murine antigen-induced arthritis. Rheumatol.2005; 44(7): 885-889.

19. Gawaz M, Langer H, May AE.Platelet in inflammation and atherogenesis, J Clin Investig, 2005; 115,:3378-3384.

20. Ojoghane E, Nwodo OFC. Comparison of extracts of Cyphostemma glaucophilla on total protein and membrane stabilization, $\mathrm{J}$ Chem and Pharm Res. 2010; 2(4): 31-37. 